Article

\title{
The Effect of Female Employment on Corporate Sustainability in Terms of Tax Avoidance
}

\author{
Chang Seop Rhee ${ }^{1} \mathbb{D}$, Sohee Woo ${ }^{2, *}$ and Dong Hyun Kim ${ }^{3}(\mathbb{D}$ \\ 1 School of Business, Sejong University, 209 Neungdong-ro, Gwangjin-gu, Seoul 05006, Korea; crhee2@sejong.ac.kr \\ 2 Global Management, Endicotte College, Woosong University, 171 Dongdaejeon-ro, Dong-gu, \\ Daejeon 34606, Korea \\ 3 College of Business and Economics, Chung-Ang University, 84 Heukseok-ro, Dongjak-gu, Seoul 06974, Korea; \\ mershkim@naver.com \\ * Correspondence: sshwoo@wsu.ac.kr; Tel.: +82-42-630-9236
}

Received: 13 November 2019; Accepted: 20 December 2019; Published: 23 December 2019

check for updates

\begin{abstract}
Recent studies on tax avoidance report that having female executives in companies increases accounting transparency and firm value by reducing tax avoidance. These studies explain that the more risk-averse and conservative characteristics of females affect corporate decision making about tax strategies if the company has female executives. In this study, we assume that the higher the proportion of female employees in a company, the more likely the risk-averse and conservative characteristics of females will affect the firm's decision making, thereby reducing tax avoidance activities and improving corporate sustainability. To verify this hypothesis, we empirically analyze the association between the female employee ratio and tax avoidance. From the empirical results, we find increasing the female employee ratio may reduce the level of tax avoidance. We also find that companies with a high percentage of female employees show less tax avoidance than those with a low percentage of female employees. The findings suggest that by increasing the ratio of female employees, a company can improve its sustainability in terms of tax avoidance by forming a risk-averse and conservative corporate environment.
\end{abstract}

Keywords: corporate sustainability; female human resources; female employment; gender-related influences; tax avoidance

\section{Introduction}

Companies must manage their cash assets efficiently for sustainable business operation. Corporate taxes are one of the expenses that causes cash outflow; therefore, companies have an incentive to make decisions to lower their corporate taxes to reduce cash outflow. The tax strategies of companies to reduce their corporate taxes has been called various terms, such, as tax avoidance, tax aggressiveness, tax sheltering, tax evasion, tax noncompliance and others, but the definition of these terms remain somewhat unclear [1-3]. This is because the definition of tax avoidance may vary depending on whether the tax strategy is carried out within legal or illegal bounds. Hanlon and Heitzman (2010) define tax avoidance broadly as the reduction of explicit tax [4]. Therefore, on the basis of their study, we define tax avoidance as all corporate actions to reduce explicit tax burdens, regardless of whether or not those actions are illegal.

Companies can reduce their cash outflow through tax avoidance, which can increase firm value in the short term [5]. However, if companies frequently carry out aggressive tax avoidance strategies, they could be detected by taxation authorities, raising the possibility of lawsuits or a damaged reputation [6]. Eventually, tax avoidance has a negative impact on corporate sustainability in the long term [7-9]. Recent studies on tax avoidance report that having female executives in companies increases accounting 
transparency and firm value by reducing tax avoidance $[10,11]$. These findings are based on studies documenting that females are more risk-averse and more conservative than males; these studies argue that female characteristics affect corporate decision making for their tax strategies if the company has female executives [12-15]. In the same vein, we assume that the higher the proportion of female employees in a company, the more likely the risk-averse and conservative characteristics of female will affect the decision making of the company, thereby reducing tax avoidance activities and improving corporate sustainability.

To verify this hypothesis, we empirically analyze the association between the female employee ratio and tax avoidance. In Korea, women's college entrance rates have been higher than those of men since 2005, and women's entry into high-ranking positions in companies has increased steeply in recent years [16]. However, the World Economic Forum (WEF) reports that women's share of estimated earned income and the perceptions of wage equality by the Korean business community are still low [17]. In other words, the Korean capital market can provide elite female human resource workers influence in a company, but their compensation in the business community is still considered unfair. This circumstance would be a good research setting in which to examine the influence of female workers in companies that are not considered to be critical for corporate sustainability. Therefore, we conducted empirical tests using 14,761 firm-year data for Korean listed firms from 2010 to 2018.

We used book-tax differences (BTD) as a proxy for tax avoidance, as with prior studies, and measured the gender-related influences by the female employee ratio $[7,18]$. From the empirical results, we find that there is a significantly negative association between the female employee ratio and BTD. This indicates that the more female employees there are, the less common the tax avoidance. We also found that companies with a high percentage of female employees show less tax avoidance than those with a low percentage of female employees. These findings support the arguments that by increasing its ratio of female employees, a company can improve its sustainability in terms of tax avoidance by forming a risk-averse and conservative corporate environment.

This study contributes to the literature in several ways. To our knowledge, this is the first study to test the direct negative association between gender-related influences and tax avoidance using the Korean stock market setting. Adding to the ongoing debate over the influence of female employees in the Korean stock market, this study finds that female employment helps companies stay sustainable by creating a more risk-averse and conservative corporate environment. We believe that our empirical evidence may create positive influences for female employment expansion in the stock market. In addition, prior tax accounting studies sought to find the determinants of tax avoidance, and this study suggests that gender diversity could also be an additional determinant of tax avoidance.

The rest of this paper is organized as follows. Section 2 discusses the prior research and develops hypothesis. Section 3 provides the research design and sample selection criteria. Section 4 documents the empirical results from the model estimation. Section 5 concludes the study.

\section{Prior Literature and Hypothesis Development}

\subsection{Tax Avoidance}

Tax avoidance theory can be divided into traditional and principal-agent perspectives. The traditional perspective is that companies can increase their shareholders' wealth through tax avoidance, which has a positive effect on firm value. In this regard, however, there is a limitation that does not explain whether corporate managers use tax avoidance to increase their shareholders' wealth. The principal-agent perspective holds that companies with separate management and ownership use tax avoidance in accordance with the managers' own interests, not for their shareholders' wealth. Thus, many studies have examined how tax avoidance affects firm value from the principal-agent perspective and have reported that, in the short term, companies may reduce their cash outflow through tax avoidance, but in the long term, this may have a negative impact on corporate sustainability by increasing the risk of litigation or damaging their reputation. 
In detail, Desai and Dharmapala (2006) and Koh et al. (2007) suggested that companies with high levels of corporate governance could improve their firm's value by reducing their corporate taxes through tax avoidance $[7,19]$. On the other hand, recent tax studies have reported that tax avoidance can be used for more opportunistic behavior, such, as earnings management, by managers, thereby reducing accounting transparency and firm value. In addition, Chen et al. (2010) explained that tax avoidance comes with direct costs, such, as the implementation cost, reputation loss, and potential punishment. Austin and Wilson (2013) further argued that companies refrain from tax avoidance because of their concern of losing their reputation with customers [20,21].

As such, from the principal-agent perspective, tax avoidance is considered to be an act of lowering corporate sustainability. Francis et al. (2014) and Shin and Lee (2018) argue that participation by female managers could be helpful in preventing tax avoidance that is detrimental to firm value $[10,11]$. They also mention that females are more risk-averse and conservative than males. Because of this gender difference, a company with female executives is less likely to be involved in tax avoidance activities [12-15]. Specifically, Francis et al. (2014) investigated the effects of gender on corporate tax aggressiveness, focusing on chief financial officer (CFO) data [10]. Even though the prior literature has provided mixed results on the gender differences in risk attitudes, current studies suggest that female CFOs indeed have higher levels of risk-aversion and predict that companies with female CFOs are more thoughtful with their aggressive tax avoidance activities. Shin and Lee (2018) also examined the influence of gender on tax avoidance using Korean firm data and assumed that, for companies with female executives, opportunistic decision-making tends to be relatively less common than in companies with only male executives [11]. Both studies provide empirical evidence for the low level of tax avoidance in companies with female executives.

\subsection{Female Employee Influences}

Recently, the rapidly changing social environment has given females increased bargaining power and opportunities to participate in economic activities. Because of this change, companies are focusing more on female-friendly business strategies for the sustainable development of companies by securing female customers. In particular, some companies are actively hiring female executives and senior managers to understand female customers and improve their existing male-dominated corporate environments [22].

Previous studies have argued that female employees improve the corporate environment by creating a diverse workforce when they are in key positions [23]. This argument can cause discontent among existing members familiar with a male-dominated corporate environment by including members of an unfamiliar gender in their organizations. However, prior studies have argued that, depending on how companies manage the diversity of the organization's members, especially their genders, they can gain competitive advantages compared to other companies. The diversity of gender among board member is important because each board member has a different perspective and experience. Thus, diversity among board member can enhance corporate innovation and strategies for the sustainable development of the corporation [24,25]. Because of the differences between females and males, an increase of the female ratio on the board is expected to have a positive impact on corporate performance and decision-making.

Kim and Hong (2015) investigated the influence of female board members on a firm's earnings management. They found that female board members are less likely to engage in earnings management than male board members, which means that female board members play a role in improving a firm's accounting transparency [26]. Adam and Ferreira (2009) and Adams et al. (2010) also found similar results to Kim and Hong $(2015)[27,28]$. They discovered that, when the ratio of the female board members increases, the transparency of their financial statements improves because of the monitoring effect caused by the diversity of board members. Bernanrdi and Arnold (1997) found that female board members are less opportunistic in their decision making than male executives [29]. This means that female executives are more risk-averse and conservative which results in improving transparency in 
financial reporting. Huang and Kisgen (2013) report that male CFOs are more interested in mergers and acquisitions (M\&A) than female CFOs due to men's tendency to be overconfident. [30] This means that, on average, female CFOs are more risk-averse than male CFOs. Similarly, Francis et al. (2014) posit that the degree of conservatism in accounting improved after the CFOs changed from female from male [10]. This study found that female CFOs have a stronger desire to avoid risks, such, as litigation risks, inherent risks, and systematic risks, in their companies than male CFOs, which leads to better transparency in their financial reporting.

\subsection{Hypothesis Development}

As the quantity of women in public affairs and female's economic activities increase, the role of females in society and corporations has become increasingly emphasized. There are many studies about the effectiveness of females as board members incorporations. The previous literature posits that diversity among board member has a positive effect on corporate performance because of the different characteristics between males and females because females are more risk-averse than males and make more conservative decisions for companies rather than aggressive acquisitions and mergers to build empires. Therefore, when a company has a higher ratio of female board members, it reports a more transparent financial statement than other companies. These results have been investigated in the US and in European countries, for companies that have more than $15 \%$ to $20 \%$ female board members. However, these results cannot be adopted easily in Korea. Since 2000, female activities in companies have increased considerably, but female employees still struggle with the glass-ceiling in male-dominated organizational culture. Accordingly, Kim (2015) finds that the female executive' ratio in Korean companies is less than $2 \%$ of the total number of executives; this ratio is the lowest among the twenty-eight OECD countries [31]. Kim and Hong (2015) posit that female board members improve accounting transparency by enhancing monitoring effects in Korea, but these results have some limitations because of the low ratio of females as board members [26]. Therefore, in this paper, we investigate the association between female employees and corporate tax avoidance.

The previous literature argues that females have more conservative and risk-averse characteristics than males in making corporate decisions. Thus, female board members can help enhance corporate transparency [13,32-34]. Unlike top executives or board members, general female employees cannot directly participate in the primary decision making. However, a diversity of members in a company may affect the foundational decisions and environment of the company to influence more important decisions. In other words, when a company has a higher female employee ratio, it can make its corporate environment less aggressive and more conservative, which could reduce the opportunistic behavior and increase the sustainability of companies in the long-term. Recent studies have reported that tax avoidance uses opportunistic behaviors and thus reduces accounting transparency $[5,35]$. Furthermore, companies with tax avoidance have a high possibility of litigation risk and a loss of reputation to their shareholders [20,21]. A diversity of employee resources, especially diversity of gender, can enhance the transparency in accounting information. Therefore, we predict that when companies have a higher ratio of female employees, which affect the company's conservatism, companies are less likely to engage in tax avoidance when reporting high performance. Hence, we produced the following hypothesis:

Hypothesis: There is a significantly negative association between the female employee ratio and tax avoidance.

\section{Research Methodology}

\subsection{Sample Selection}

This study selects a final sample of companies listed on the Korean stock market (KOSPI and KSDAQ) that meets the following requirements: (1) They are not included in the financial industry, (2) they provide financial statement information and employee data, which are required to compute the main variables, and (3) they close their accounts in December. A total of 14,761 observations were used in the empirical 
analysis of this study from 2010 to 2018. Table 1 provides a sample distribution according to the fiscal year and industry, respectively. Panel A in Table 1 features a sample distribution of the firm-year observations for empirical testing. The total number of sample data is 14,716, from 2011 to 2018. Industry definitions are based on the Korean standard industrial classification (KSIC) in Panel B, and manufacturing industry makes up the largest portion of the sample in this study, at $65.75 \%$.

Table 1. Sample Distributions.

\begin{tabular}{|c|c|c|}
\hline \multicolumn{3}{|l|}{ Panel A: Sample Distribution by Year } \\
\hline Year & No. of Obs. & $\%$ \\
\hline 2010 & 1834 & 12.42 \\
\hline 2011 & 1380 & 9.35 \\
\hline 2012 & 1448 & 9.81 \\
\hline 2013 & 1514 & 10.26 \\
\hline 2014 & 1542 & 10.45 \\
\hline 2015 & 1626 & 11.02 \\
\hline 2016 & 1715 & 11.62 \\
\hline 2017 & 1790 & 12.13 \\
\hline 2018 & 1912 & 12.95 \\
\hline Total & 14,761 & 100.00 \\
\hline \multicolumn{3}{|l|}{ Panel B: Sample Distribution by Industry } \\
\hline Industry & No. of Obs. & $\%$ \\
\hline Agriculture, forestry and fishing & 42 & 0.28 \\
\hline Mining & 29 & 0.20 \\
\hline Manufacturing & 9705 & 65.75 \\
\hline Supply of electricity, gas, steam and air conditioning & 100 & 0.68 \\
\hline Water, sewage and waste disposal, raw material regeneration & 60 & 0.41 \\
\hline Construction & 486 & 3.29 \\
\hline Wholesale and retailing & 1205 & 8.16 \\
\hline Transportation and warehouse business & 242 & 1.64 \\
\hline Accommodation and restaurant business & 13 & 0.09 \\
\hline Information and communication business & 1572 & 10.65 \\
\hline Real estate industry & 33 & 0.22 \\
\hline Professional, scientific and technical services & 938 & 6.35 \\
\hline Business facilities management, business support and lease service & 150 & 1.02 \\
\hline Educational service & 85 & 0.58 \\
\hline Arts, sports and leisure-related services & 91 & 0.62 \\
\hline Association and organization, repair and other personal services & 10 & 0.07 \\
\hline Total & 14,761 & 100.00 \\
\hline
\end{tabular}

\subsection{Measures of the Female Employee Ratio (FER) and Book-Tax Difference (BTD)}

In recent studies, the female employee ratio has been used as a proxy variable for gender diversity. This means that the female employee ratio is valid as a measure that can directly link corporate annual financial data to gender diversity [36,37]. We collected the status of employees provided by the TS2000 database to calculate the female employee ratio. In Korea, the contract types of employment are generally divided into regular and non-regular employment [38-40]. Korea's regular and non-regular employment is very similar to the concept of permanent and contingent employment in the U.S. in terms of working on a full-time or part-time basis and contract periods [41-44]. However, in the case of Korea, the difference in the benefits and influence of regular employees is incomparably higher than that of non-regular employees, while the working hours of both regular and non-regular employees are almost identical $[45,46]$. Therefore, we used the firm-year data for regular employees to measure 
the female employee ratio in this study. The female employee ratio measurement variable (FER) is calculated according to the equation 1 below.

$$
\text { Female Employee Ratio }(F E R)=\frac{\text { Number of female regular employees }}{\text { Number of total regular employees }} .
$$

In addition, we create a dummy variable of HFER below using the median value of the female employee rate. We divide the female employee ratio into two groups of companies with high and low female employee ratios. If a company's female employment ratio is higher than the median value of the overall female employment ratio, it is classified as a company with a higher female employment ratio $(H F E R=1)$. On the other hand, if a company's female employment ratio is lower than the median value of the overall female employment ratio, it is classified as a company with a lower female employment ratio $(H F E R=0)$.

High female employee ratio (HFER) is a dummy variable; its value is 1 if the female employee ratio is higher than the median value of the sample, and 0 otherwise.

The information for taxable income is required to compute the BTD variable; however, these data are undisclosed to public. Therefore, we need to estimate taxable income through reported income tax expenses. In this study, we refer the method of Lev and Nissim (2004) to measure the estimated taxable income using the corporate tax rate in Korea (Table 2) and compute the BTD by subtracting the estimated taxable income from earnings before income tax [18].

$$
\text { Estimated taxable income }=\frac{\text { Income tax expense }}{\text { Corporate tax rate }}
$$

Book-Tax Difference $(B T D)=($ Earnings before Income Tax $)-($ Estimated Taxable Income $)$.

Table 2. Corporate Tax Rate in Korea.

\begin{tabular}{ccc}
\hline Year & Tax Income & Tax rate \\
\hline \multirow{2}{*}{$2010-2011$} & Less than 200 million & $10 \% \times 1.1=11.0 \%$ \\
& More than 200 million & $22 \% \times 1.1=24.2 \%$ \\
\hline \multirow{2}{*}{$2012-2017$} & Less than 200 million & $10 \% \times 1.1=11.0 \%$ \\
& More than 200 million to 20 billion or less & $20 \% \times 1.1=22.0 \%$ \\
More than 20 billion & $22 \% \times 1.1=24.2 \%$ \\
\hline \multirow{2}{*}{2018} & Less than 200 million & $10 \% \times 1.1=11.0 \%$ \\
& More than 200 million to 20 billion or less & $20 \% \times 1.1=22.0 \%$ \\
& More than 20 billion to 300 billion or less & $22 \% \times 1.1=24.2 \%$ \\
& More than 300 billion & $25 \% \times 1.1=27.5 \%$ \\
\hline
\end{tabular}

Resource: Korea National Tax Service [47]. Unit: Korean won.

\subsection{Regression Model}

This study establishes the following regression model to empirically verify the gender-related influences on tax avoidance. Descriptions of the variables for our regression model are given in Table 3. The dependent variable is $B T D$, and independent variables are FER and HFER. We include control variables (SIZE, ROA, LEV, INVREV, $\triangle T A, \triangle E B I T, \triangle D E B T, O C F, T A X$, and LARGE) that affect the BTD in our regression Model 1-1 and Model 1-2. To control the influence of firm size and firm performance, SIZE, ROA, LEV, and INVREV are included in the models [5,48]. Kim and Jeong (2006) report that the change rates of firm size and firm performance affect tax avoidance [49]. Therefore, we add the change rate variables of $\triangle T A, \triangle E B I T$, and $\triangle D E B T$ into the models. Finally, $O C F, T A X$, and $L A R G E$ are used as control variables to eliminate the effect of a firm's operating cash flows, income tax expenses, and large shareholder ownership rates on tax avoidance [50,51]. 
[Model 1-1]

$B T D_{i, t}=\beta_{0}+\beta_{1} F E R_{i, t}+\beta_{2} S I Z E_{i, t}+\beta_{3} R O A_{i, t}+\beta_{4} L E V_{i, t}+\beta_{5} I N V R E V_{i, t}+\beta_{6} \Delta T A_{i, t}+\beta_{7} \triangle E B I T_{i, t}+$ $\beta_{8} \triangle D E B T_{i, t}+\beta_{9} O C F_{i, t}+\beta_{10} T A X_{i, t}+\beta_{11} L A R G E_{i, t}+\sum Y D+\sum I N D+\varepsilon_{i, t}$

[Model 1-2]

$$
\begin{aligned}
& B T D_{i, t}=\beta_{0}+\beta_{1} H_{F E R_{i, t}}+\beta_{2} S_{I Z E_{i, t}}+\beta_{3} R O A_{i, t}+\beta_{4} L E V_{i, t}+\beta_{5} I N V R E V_{i, t}+\beta_{6} \Delta \mathrm{TA}_{i, t}+\beta_{7} \triangle E B I T_{i, t}+ \\
& \beta_{8} \triangle D E B T_{i, t}+\beta_{9} O C F_{i, t}+\beta_{10} T A X_{i, t}+\beta_{11} L A R G E_{i, t}+\sum Y D+\sum I N D+\varepsilon_{i, t}
\end{aligned}
$$

\begin{tabular}{|c|c|c|}
\hline \multicolumn{2}{|c|}{ Variables } & Explanation \\
\hline Dependent Variable & $B T D_{i, t}$ & $\begin{array}{l}\text { Tax avoidance measure; } \\
\text { Book-tax difference for firm } i \text { in year } t / \text { total assets for firm } i \text { in year } t-1\end{array}$ \\
\hline \multirow[t]{2}{*}{ Independent Variables } & $F E R_{i, t}$ & $\begin{array}{l}\text { Female Employee Ratio; } \\
\text { Number of female employees/Number of total employees for firm } i \text { in year } t\end{array}$ \\
\hline & $H F E R_{i, t}$ & $\begin{array}{l}\text { A dummy variable; } 1 \text { if the female employee ratio is higher than the median value of } \\
\text { the sample, and } 0 \text { otherwise. }\end{array}$ \\
\hline \multirow{12}{*}{ Control Variables } & $S I Z E_{i, t}$ & Natural $\log$ of total assets for firm $i$ in year $t-1$ \\
\hline & $R O A_{i, t}$ & Earnings before income tax/total assets for firm $i$ in year $t-1$ \\
\hline & $L E V_{i, t}$ & Total liability/total assets for firm $i$ in year $t-1$ \\
\hline & $I N V R E V_{i, t}$ & Inventory and account receivable for firm $i$ in year $t /$ total assets for firm $i$ in year $t-1$ \\
\hline & $\triangle T A_{i, t}$ & Change of total asset for firm $i$ in year $t /$ total assets for firm $i$ in year $t-1$ \\
\hline & $\triangle E B I T_{i, t}$ & $\begin{array}{l}\text { Change of earnings before income tax for firm } i \text { in year } t \text { /earnings before income tax } \\
\text { for firm } i \text { in year } t-1\end{array}$ \\
\hline & $\triangle D E B T_{i, t}$ & Change of liability for firm $i$ in year $t /$ total assets for firm $i$ in year $t-1$ \\
\hline & $O C F_{i, t}$ & Operating cash flow for firm $i$ in year $t /$ total assets for firm $i$ in year $t-1$ \\
\hline & $\mathrm{TAX}_{i, t}$ & $\begin{array}{l}\text { Corporate tax rate; Income tax expense for firm } i \text { in year } t / \text { Earnings before income tax } \\
\text { for firm } i \text { in year } t\end{array}$ \\
\hline & $L A R G E_{i, t}$ & Ratio of largest shareholder for firm $i$ in year $t$ \\
\hline & $\sum Y D$ & Year dummy \\
\hline & $\sum I N D$ & Industry dummy \\
\hline
\end{tabular}

Table 3. The Explanation of Variables.

\section{Empirical Results}

\subsection{Descriptive Statistics}

Table 4 reports descriptive statistics for the variables used in this study. In order to minimize the effect of extreme values, we winsorize the top and bottom $1 \%$ of all variables. The mean and median value for a measure of tax avoidance $(B T D)$ is -0.059 and -0.045 respectively. The mean value of the female employee ratio (FER) is 0.216 , which indicates that listed Korean companies have approximately $21.6 \%$ female employees, on average, compared to their total employees. The median value of FER is 0.170 . HFER is a dummy variable based on the median ratio of the female employee ratio (FER). If a company's FER is greater than 0.170 , its HFER is equal to one, indicating that the company belongs to the high female employee ratio group. On the other hand, if a company's FER is less than 0.170, it HFER is equal to zero, indicating that the company belongs to the low female employee ratio group. The mean value of HFER is 0.500 , which indicates that $50 \%$ of the sample companies have at least $17 \%$ of female employees among their total number of employees. The descriptive values of the other control variables are generally consistent with those of prior studies $[5,11]$. 
Table 4. Descriptive Statistics.

\begin{tabular}{cccccccc}
\hline Variables & Mean & Std. & Min. & Q1 & Median & Q3 & Max. \\
\hline BTD & -0.059 & 0.175 & -0.683 & -0.129 & -0.045 & 0.011 & 0.597 \\
FER & 0.216 & 0.162 & 0.005 & 0.087 & 0.170 & 0.306 & 0.696 \\
HFER & 0.500 & 0.500 & 0.000 & 0.000 & 0.000 & 1.000 & 1.000 \\
SIZE & 18.940 & 1.391 & 16.530 & 17.992 & 18.664 & 19.615 & 23.627 \\
LEV & 0.416 & 0.232 & 0.025 & 0.230 & 0.403 & 0.572 & 1.121 \\
$I N V R E V$ & 0.286 & 0.182 & 0.001 & 0.150 & 0.264 & 0.396 & 0.851 \\
ROA & 0.017 & 0.111 & -0.447 & -0.008 & 0.028 & 0.068 & 0.304 \\
$\triangle T A$ & 0.087 & 0.243 & -0.385 & -0.019 & 0.036 & 0.135 & 1.359 \\
$\triangle E B I T$ & -0.422 & 4.195 & -26.605 & -0.783 & -0.111 & 0.341 & 15.544 \\
$\triangle D E B T$ & 0.127 & 0.546 & -0.700 & -0.105 & 0.011 & 0.194 & 3.401 \\
OCF & 0.044 & 0.094 & -0.268 & -0.003 & 0.042 & 0.094 & 0.325 \\
TAX & 0.125 & 0.348 & -1.796 & 0.000 & 0.171 & 0.237 & 1.572 \\
LARGE & 0.383 & 0.184 & 0.002 & 0.255 & 0.386 & 0.511 & 0.789 \\
\hline
\end{tabular}

Notes: See Table 3 for the explanation of variables.

\subsection{Univariate Analysis}

Table 5 provides the Pearson correlation result, which shows the correlation of the variables used in this study. The FER is negatively associated with BTD at a significant level. This negative association suggests that the higher the ratio of female employment in a company, the less frequent the company's tax avoidance. Further, there is a significantly negative association between HFER and BTD, which means that the level of BTD for companies with higher female employee ratios is lower than that for companies with lower female employee ratios. The results of the univariate analysis support our hypothesis but could reveal a limitation, as this analysis did not control the influence of the other variables. Therefore, we perform a multivariate analysis to examine the effects of female variables (FER and HFER) on BTD, including the control variables.

Table 5. Pearson Correlation.

\begin{tabular}{|c|c|c|c|c|c|c|c|c|c|c|c|c|}
\hline Variables & $B T D$ & FER & HFER & SIZE & $L E V$ & INVREI & VROA & $\triangle T A$ & $\triangle E B I T$ & $\triangle D E B T$ & OCF & $T A X$ \\
\hline FER & $\begin{array}{l}-0.070 \\
(0.000)\end{array}$ & & & & & & & & & & & \\
\hline HFER & $\begin{array}{l}-0.066 \\
(0.000)\end{array}$ & $\begin{array}{l}0.778 \\
(0.000)\end{array}$ & & & & & & & & & & \\
\hline SIZE & $\begin{array}{l}0.102 \\
(0.000)\end{array}$ & $\begin{array}{l}-0.148 \\
(0.000)\end{array}$ & $\begin{array}{c}-0.158 \\
(0.000)\end{array}$ & & & & & & & & & \\
\hline$L E V$ & $\begin{array}{l}0.100 \\
(0.000)\end{array}$ & $\begin{array}{l}-0.102 \\
(0.000)\end{array}$ & $\begin{array}{c}-0.112 \\
(0.000)\end{array}$ & $\begin{array}{l}0.124 \\
(0.000)\end{array}$ & & & & & & & & \\
\hline INVREV & $\begin{array}{l}0.050 \\
(0.000)\end{array}$ & $\begin{array}{l}-0.132 \\
(0.000)\end{array}$ & $\begin{array}{c}-0.126 \\
(0.000)\end{array}$ & $\begin{array}{c}-0.114 \\
(0.000)\end{array}$ & $\begin{array}{l}0.384 \\
(0.000)\end{array}$ & & & & & & & \\
\hline$R O A$ & $\begin{array}{l}0.244 \\
(0.000)\end{array}$ & $\begin{array}{l}-0.065 \\
(0.000)\end{array}$ & $\begin{array}{r}-0.062 \\
(0.000)\end{array}$ & $\begin{array}{l}0.145 \\
(0.000)\end{array}$ & $\begin{array}{l}-0.157 \\
(0.000)\end{array}$ & $\begin{array}{l}0.169 \\
(0.000)\end{array}$ & & & & & & \\
\hline$\triangle T A$ & $\begin{array}{l}0.092 \\
(0.000)\end{array}$ & $\begin{array}{l}0.073 \\
(0.000)\end{array}$ & $\begin{array}{l}0.064 \\
(0.000)\end{array}$ & $\begin{array}{c}-0.184 \\
(0.000)\end{array}$ & $\begin{array}{l}0.336 \\
(0.000)\end{array}$ & $\begin{array}{l}0.259 \\
(0.000)\end{array}$ & $\begin{array}{l}0.245 \\
(0.000)\end{array}$ & & & & & \\
\hline$\triangle E B I T$ & $\begin{array}{l}-0.019 \\
(0.022)\end{array}$ & $\begin{array}{l}-0.013 \\
(0.104)\end{array}$ & $\begin{array}{l}-0.007 \\
(0.370)\end{array}$ & $\begin{array}{l}0.025 \\
(0.003)\end{array}$ & $\begin{array}{l}-0.021 \\
(0.013)\end{array}$ & $\begin{array}{l}0.021 \\
(0.012)\end{array}$ & $\begin{array}{l}0.141 \\
(0.000)\end{array}$ & $\begin{array}{l}0.043 \\
(0.000)\end{array}$ & & & & \\
\hline$\triangle D E B T$ & $\begin{array}{l}0.032 \\
(0.000)\end{array}$ & $\begin{array}{l}0.039 \\
(0.000)\end{array}$ & $\begin{array}{l}0.040 \\
(0.000)\end{array}$ & $\begin{array}{l}-0.128 \\
(0.000)\end{array}$ & $\begin{array}{l}0.324 \\
(0.000)\end{array}$ & $\begin{array}{l}0.128 \\
(0.000)\end{array}$ & $\begin{array}{c}-0.022 \\
(0.009)\end{array}$ & $\begin{array}{l}0.580 \\
(0.000)\end{array}$ & $\begin{array}{l}-0.009 \\
(0.263)\end{array}$ & & & \\
\hline$O C F$ & $\begin{array}{l}0.016 \\
(0.058)\end{array}$ & $\begin{array}{l}-0.031 \\
(0.000)\end{array}$ & $\begin{array}{c}-0.032 \\
(0.000)\end{array}$ & $\begin{array}{l}0.111 \\
(0.000)\end{array}$ & $\begin{array}{l}-0.124 \\
(0.000)\end{array}$ & $\begin{array}{l}-0.068 \\
(0.000)\end{array}$ & $\begin{array}{l}0.534 \\
(0.000)\end{array}$ & $\begin{array}{l}0.063 \\
(0.000)\end{array}$ & $\begin{array}{l}0.077 \\
(0.000)\end{array}$ & $\begin{array}{l}-0.035 \\
(0.000)\end{array}$ & & \\
\hline TAX & $\begin{array}{l}-0.064 \\
(0.000)\end{array}$ & $\begin{array}{c}-0.014 \\
(0.094)\end{array}$ & $\begin{array}{c}-0.019 \\
(0.019)\end{array}$ & $\begin{array}{l}0.139 \\
(0.000)\end{array}$ & $\begin{array}{c}-0.014 \\
(0.085)\end{array}$ & $\begin{array}{l}0.027 \\
(0.001)\end{array}$ & $\begin{array}{l}0.137 \\
(0.000)\end{array}$ & $\begin{array}{l}0.015 \\
(0.064)\end{array}$ & $\begin{array}{l}0.040 \\
(0.000)\end{array}$ & $\begin{array}{l}-0.013 \\
(0.126)\end{array}$ & $\begin{array}{l}0.094 \\
(0.000)\end{array}$ & \\
\hline$L A R G E$ & $\begin{array}{l}0.034 \\
(0.000)\end{array}$ & $\begin{array}{l}-0.022 \\
(0.008)\end{array}$ & $\begin{array}{l}-0.053 \\
(0.000)\end{array}$ & $\begin{array}{l}0.093 \\
(0.000)\end{array}$ & $\begin{array}{l}-0.076 \\
(0.000)\end{array}$ & $\begin{array}{l}0.002 \\
(0.780)\end{array}$ & $\begin{array}{l}0.200 \\
(0.000)\end{array}$ & $\begin{array}{l}0.028 \\
(0.001)\end{array}$ & $\begin{array}{l}0.023 \\
(0.006)\end{array}$ & $\begin{array}{l}-0.019 \\
(0.022)\end{array}$ & $\begin{array}{l}0.124 \\
(0.000)\end{array}$ & $\begin{array}{l}0.090 \\
(0.000)\end{array}$ \\
\hline
\end{tabular}

Notes: Parentheses indicate $p$-value. See Table 3 for the explanation of variables. 


\subsection{Multivariate Analysis}

Table 6 shows the regression results for the hypothesis. In Model 1-1 of Table 6, the coefficient of FER is -0.027 ( $t$-value $=-2.97$ ), which is significant at a $1 \%$ level with $B T D$, implying that, for each $1 \%$ increase in the female employee ratio, the possibility of tax avoidance decreases by $2.7 \%$. The negative association between FER and BTD supports our hypothesis. With a high ratio of female employees, a company can reduce tax avoidance because of the propensity for females to be more risk-averse and conservative than males. The coefficients of SIZE, ROA, and LEV are significantly positive, while the coefficients of INVREV, $\triangle T A, \triangle E B I T, O C F, T A X$, and $L A R G E$ are significantly negative. The adjusted R-squared value of $15.48 \%$ and the low maximum variance inflation factor (VIF) value indicates the goodness of fit of this model for the empirical test.

Model 1-2 in Table 6 presents the regression results using the HFER variable. HFER is a dummy variable divided into companies with high or low female employee ratios compared with the median of the female employee ratio of the total sample. The coefficient of HFER is -0.008 ( $t$-value $=-2.84)$, which is statistically significant at a $1 \%$ level. The negative association between HFER and BTD indicates that the companies with a high female employee ratio engage in less tax avoidance than those with a low female employee ratio. Most control variables are significantly associated with BTD except $\triangle D E B T$, and the adjusted R-squared value and maximum VIF value are nearly same as the results from Model 1-1. These results are consistent with our hypothesis and suggest that female employees are an important factor in corporate sustainability in terms of tax avoidance.

Table 6. The Results of Multivariate Analysis.

\begin{tabular}{|c|c|c|c|c|c|c|}
\hline \multirow{3}{*}{ Variables } & \multicolumn{6}{|c|}{ Dependent Variable: $B T D$} \\
\hline & \multicolumn{3}{|c|}{ Model 1-1 } & \multicolumn{3}{|c|}{ Model 1-2 } \\
\hline & \multicolumn{2}{|c|}{ Coefficient } & \multirow{2}{*}{$\frac{t \text {-Statistics }}{-3.22}$} & \multicolumn{2}{|c|}{ Coefficient } & \multirow{2}{*}{$\frac{t \text {-Statistics }}{-3.32}$} \\
\hline Intercept & -0.181 & $* * *$ & & -0.186 & $* * *$ & \\
\hline FER & -0.027 & $* * *$ & -2.97 & & & \\
\hline HFER & & & & -0.008 & $* * *$ & -2.84 \\
\hline SIZE & 0.005 & $* * *$ & 4.38 & 0.005 & $* * *$ & 4.39 \\
\hline$R O A$ & 0.617 & $* * *$ & 36.84 & 0.618 & $* * *$ & 36.89 \\
\hline$L E V$ & 0.124 & $* * *$ & 16.79 & 0.124 & $* * *$ & 16.78 \\
\hline INVREV & -0.112 & $* * *$ & -12.25 & -0.112 & $* * *$ & -12.24 \\
\hline$\triangle T A$ & -0.013 & $*$ & -1.67 & -0.013 & * & -1.73 \\
\hline$\triangle E B I T$ & -0.002 & $* * *$ & -6.64 & -0.002 & $* * *$ & -6.61 \\
\hline$\triangle D E B T$ & 0.000 & & 0.11 & 0.000 & & 0.14 \\
\hline OCF & -0.305 & $* * *$ & -17.76 & -0.305 & $* * *$ & -17.76 \\
\hline TAX & -0.050 & $* * *$ & -12.81 & -0.050 & $* * *$ & -12.82 \\
\hline LARGE & -0.014 & $*$ & -1.81 & -0.015 & * & -1.90 \\
\hline Year Dummy & \multicolumn{3}{|c|}{ Include } & \multicolumn{3}{|c|}{ Include } \\
\hline Industry Dummy & \multicolumn{3}{|c|}{ Include } & \multicolumn{3}{|c|}{ Include } \\
\hline$F$-value & \multicolumn{3}{|c|}{80.51} & \multicolumn{3}{|c|}{80.48} \\
\hline Adj. R2 & \multicolumn{3}{|c|}{0.1548} & \multicolumn{3}{|c|}{0.1548} \\
\hline Max. VIF & \multicolumn{3}{|c|}{1.991} & \multicolumn{3}{|c|}{1.986} \\
\hline No. of Obs. & \multicolumn{3}{|c|}{14,761} & \multicolumn{3}{|c|}{14,761} \\
\hline
\end{tabular}

Note: ${ }^{* * *}$ and $*$ represent a significant at the $1 \%, 5 \%$, and $10 \%$ level or less, respectively. See Table 3 for the explanation of variables.

\subsection{Additional Test}

We measure the female employee ratio (FER) using only regular employees with strong positions in the company, but the status of non-regular employee has improved recently in Korea, with an increase 
in the number of non-regular employees. Therefore, we additionally create FER2, which includes non-regular employees to take into account their influence in the company:

Female Employee Ratio2 $($ FER2 $)=\frac{\text { Number of regular female employees }+ \text { Number of non-regular female employees }}{\text { Number of total regular employees }+ \text { Number of total non-regular employees }}$.

We set up the following Models (2-1 and 2-2) for an additional test. HFER2 is a dummy variable: Its value is 1 if the female employee ratio based on both regular and non-regular employees is higher than the median value of the sample and 0 otherwise. We use FER2 and HFER2 as independent variables in Model 2-1 and Model 2-2.

[Model 2-1]

$B T D_{i, t}=\beta_{0}+\beta_{1} F E R 2_{i, t}+\beta_{2} S I Z E_{i, t}+\beta_{3} R O A_{i, t}+\beta_{4} L E V_{i, t}+\beta_{5} I N V R E V_{i, t}+\beta_{6} \Delta T A_{i, t}+\beta_{7} \triangle E B I T_{i, t}+$ $\beta_{8} \triangle D E B T_{i, t}+\beta_{9} O C F_{i, t}+\beta_{10} T A X_{i, t}+\beta_{11} L A R G E_{i, t}+\sum Y D+\sum I N D+\varepsilon_{i, t}$

[Model 2-2]

$B T D_{i, t}=\beta_{0}+\beta_{1} H F E R 2_{i, t}+\beta_{2} \operatorname{SIZE}_{i, t}+\beta_{3} R O A_{i, t}+\beta_{4} L E V_{i, t}+\beta_{5} I N V R E V_{i, t}+\beta_{6} \triangle T A_{i, t}+\beta_{7} \triangle E B I T_{i, t}+$ $\beta_{8} \triangle D E B T_{i, t}+\beta_{9} O C F_{i, t}+\beta_{10} T A X_{i, t}+\beta_{11} L A R G E_{i, t}+\sum Y D+\sum I N D+\varepsilon_{i, t}$

Model 2-1 in Table 7 shows the regression results between the FER2 and BTD. The coefficient of FER2 is $-0.030(t=-3.34)$ and is statistically significant at a $1 \%$ level. This result means that when the female employee ratio, including both regular and non-regular employees, is increased by $1 \%$, then the possibility of tax avoidance is decreased by $3.0 \%$. That is, the result remains the same as in Model 1-1 in Table 6, even if non-regular employees are included.

Table 7. The Results of Additional Test.

\begin{tabular}{|c|c|c|c|c|c|c|}
\hline \multirow{3}{*}{ Variables } & \multicolumn{6}{|c|}{ Dependent Variable: $B T D$} \\
\hline & \multicolumn{3}{|c|}{ Model 2-1 } & \multicolumn{3}{|c|}{ Model 2-2 } \\
\hline & \multicolumn{2}{|c|}{ Coefficient } & \multirow{2}{*}{$\begin{array}{c}t \text {-Statistics } \\
-3.13\end{array}$} & \multicolumn{2}{|c|}{ Coefficient } & \multirow{2}{*}{$\frac{t \text {-Statistic }}{-3.32}$} \\
\hline Intercept & -0.176 & $* * *$ & & -0.186 & $* * *$ & \\
\hline FER2 & -0.030 & $* * *$ & -3.34 & & & \\
\hline HFER2 & & & & -0.008 & $* * *$ & -2.84 \\
\hline SIZE & 0.005 & $* * *$ & 4.37 & 0.005 & $* * *$ & 4.39 \\
\hline$R O A$ & 0.617 & $* * *$ & 36.85 & 0.618 & $* * *$ & 36.91 \\
\hline$L E V$ & 0.124 & $* * *$ & 16.80 & 0.124 & $* * *$ & 16.79 \\
\hline INVREV & -0.112 & $* * *$ & -12.28 & -0.112 & $* * *$ & -12.25 \\
\hline$\triangle \mathrm{TA}$ & -0.013 & * & -1.65 & -0.013 & * & -1.72 \\
\hline$\triangle E B I T$ & -0.002 & $* * *$ & -6.65 & -0.002 & $* * *$ & -6.62 \\
\hline$\triangle D E B T$ & 0.000 & & 0.10 & 0.000 & & 0.14 \\
\hline OCF & -0.305 & $* * *$ & -17.76 & -0.305 & $* * *$ & -17.77 \\
\hline TAX & -0.050 & $* * *$ & -12.81 & -0.050 & $* * *$ & -12.82 \\
\hline LARGE & -0.014 & $*$ & -1.80 & -0.015 & $*$ & -1.90 \\
\hline Year Dummy & & Include & & & Include & \\
\hline Industry Dummy & & Include & & & Include & \\
\hline$F$-value & & 80.59 & & & 80.48 & \\
\hline Adj. R2 & & 0.1549 & & & 0.1548 & \\
\hline Max. VIF & & 1.990 & & & 1.987 & \\
\hline N. of Obs. & & 14,761 & & & 14,761 & \\
\hline
\end{tabular}

Note: ${ }^{* * *}$ and ${ }^{*}$ represent a significant at the $1 \%, 5 \%$, and $10 \%$ level or less, respectively. See Table 3 for the explanation of variables.

We also create a dummy variable for HFER2, which includes non-regular employees. In Model 2-2, the coefficient of HFER is $-0.008(t=2.84)$ and is statistically significant at a $1 \%$ level. The negative association between HFER and BTD means that companies with a high female employee ratio engage in less tax avoidance than those with a low female employee ratio, even if one includes the influence 
of non-regular employees. The results in Table 7 are very similar to our main results in Table 6 and support the hypothesis that a high female employee ratio may reduce the possibility of tax avoidance.

\subsection{Robustness Test}

A company's taxable income is not disclosed to the public, and prior studies have estimated taxable income to calculate the BTD. However, Desai and Dharmapala (2006) argue that BTD contains tax avoidance information, but this information might not be accurate as a proxy [7] because the computed BTD includes noise factors other than tax avoidance. These factors eliminate the effects of earning management for financial reporting purposes from the BTD to estimate a more accurate BTD. For the robustness test, we estimate the residual value using the equation below in accordance with the method of Desai and Dharmapala (2006), thereby creating a measure of the tax avoidance variable, DD [7].

$$
B T D_{i, t}=\beta_{1} T_{A C C} i, t+\mu_{i}+\varepsilon_{i, t}
$$

where BTD is book-tax difference, scaled by the lagged value of total assets, TACC is total accruals, scaled by the lagged value of total assets, $\mu$ is the average value of the residual over the sample period 2010-2018, and $\varepsilon$ is the deviation.

We established Model 3-1 and Model 3-2 using the $D D$ variable as a dependent variable to perform the robustness test. The setting of the independent variable and the control variables is the same as in Model 1-1 and Model 1-2.

[Model 3-1]

$D D_{i, t}=\beta_{0}+\beta_{1} F E R_{i, t}+\beta_{2} S I Z E_{i, t}+\beta_{3} R O A_{i, t}+\beta_{4} L E V_{i, t}+\beta_{5} I N V R E V_{i, t}+\beta_{6} \Delta T A_{i, t}+\beta_{7} \triangle E B I T_{i, t}+$ $\beta_{8} \triangle D E B T_{i, t}+\beta_{9} O C F_{i, t}+\beta_{10} T A X_{i, t}+\beta_{11} L A R G E_{i, t}+\sum Y D+\sum I N D+\varepsilon_{i, t}$

[Model 3-2]

$D D_{i, t}=\beta_{0}+\beta_{1} \operatorname{HFER}_{i, t}+\beta_{2} \operatorname{SIZE}_{i, t}+\beta_{3} R O A_{i, t}+\beta_{4} L E V_{i, t}+\beta_{5} I N V R E V_{i, t}+\beta_{6} \Delta T A_{i, t}+\beta_{7} \triangle E B I T_{i, t}+$ $\beta_{8} \triangle D E B T_{i, t}+\beta_{9} O C F_{i, t}+\beta_{10} T A X_{i, t}+\beta_{11} L A R G E_{i, t}+\sum Y D+\sum I N D+\varepsilon_{i, t}$

where DD is a measure of tax avoidance computed by the method of Desai Dharmapala (2006) [7].

Table 8 shows the results of the robustness test by using $D D$ as a dependent variable based on the method of Desai and Dharmapala (2006). In Model 3-1 (Table 8), we observe that the coefficient of FER is $-0.009(t=-3.05)$ and is statistically significant at a $1 \%$ level. This result for the negative association between female employee ratio $(F E R)$ and tax avoidance $(D D)$ is consistent with the results of the main analysis and the additional test and supports the hypothesis that an increase in the female employee ratio may cause a reduction in tax avoidance.

In Model 3-2, the coefficient of HFER is $-0.029(t=-3.23)$ and is statistically significant at a $1 \%$ level. This result of the negative association between a high female employee ratio group (HFER) and tax avoidance $(D D)$ is consistent with the results of the main analysis and the additional test and means that the group of companies with a high female employee ratio reports less tax avoidance than those with a low female employee ratio. We used elaborated measurements from Desai and Dharmapala (2006), and our main results remained the same. In other words, we conclude that a company with a high female employee ratio is less likely to engage in tax avoidance because of the female characteristics of risk-aversion and conservatism based on our empirical test results. Our conclusions from these empirical results are in line with Kim and Jeong (2018)'s argument that the possibility for earnings management activities decreases as the female employee ratio increases. 
Table 8. The Results of Robustness Test.

\begin{tabular}{|c|c|c|c|c|c|c|}
\hline \multirow{3}{*}{ Variables } & \multicolumn{6}{|c|}{ Dependent Variable: $D D$} \\
\hline & \multicolumn{3}{|c|}{ Model 3-1 } & \multicolumn{3}{|c|}{ Model 3-1 } \\
\hline & \multicolumn{2}{|c|}{ Coefficient } & \multirow{2}{*}{$\begin{array}{c}t \text {-Statistics } \\
-3.31\end{array}$} & \multicolumn{2}{|c|}{ Coefficient } & \multirow{2}{*}{$\frac{t \text {-Statistic }}{-3.19}$} \\
\hline Intercept & -0.188 & $* * *$ & & -0.182 & $* * *$ & \\
\hline FER & -0.009 & $* * *$ & -3.05 & & & \\
\hline HFER & & & & -0.029 & $* * *$ & -3.23 \\
\hline SIZE & 0.004 & $* * *$ & 3.93 & 0.004 & $* * *$ & 3.92 \\
\hline$R O A$ & -0.026 & & -1.54 & -0.027 & & -1.58 \\
\hline LEV & 0.117 & $* * *$ & 15.60 & 0.117 & $* * *$ & 15.61 \\
\hline INVREV & -0.100 & $* * *$ & -10.79 & -0.100 & $* * *$ & -10.81 \\
\hline$\triangle T A$ & -0.018 & $* *$ & -2.27 & -0.017 & $* *$ & -2.21 \\
\hline$\triangle E B I T$ & -0.002 & $* * *$ & -5.58 & -0.002 & $* * *$ & -5.61 \\
\hline$\triangle D E B T$ & 0.004 & & 1.40 & 0.004 & & 1.36 \\
\hline OCF & 0.320 & $* * *$ & 18.39 & 0.320 & $* * *$ & 18.39 \\
\hline$T A X$ & -0.049 & $* * *$ & -12.48 & -0.049 & $* * *$ & -12.47 \\
\hline LARGE & -0.013 & & -1.63 & -0.012 & & -1.54 \\
\hline Year Dummy & \multicolumn{3}{|c|}{ Include } & \multicolumn{3}{|c|}{ Include } \\
\hline Industry Dummy & \multicolumn{3}{|c|}{ Include } & \multicolumn{3}{|c|}{ Include } \\
\hline$F$-value & \multicolumn{3}{|c|}{45.88} & \multicolumn{3}{|c|}{45.91} \\
\hline Adj. R2 & \multicolumn{3}{|c|}{0.0937} & \multicolumn{3}{|c|}{0.0938} \\
\hline Max. VIF & \multicolumn{3}{|c|}{1.986} & \multicolumn{3}{|c|}{1.991} \\
\hline N. of Obs. & \multicolumn{3}{|c|}{14,761} & \multicolumn{3}{|c|}{14,761} \\
\hline
\end{tabular}

Note: ${ }^{* * * * *}$ and ${ }^{*}$ represent a significant at the $1 \%, 5 \%$, and $10 \%$ level or less, respectively. See Table 3 for the explanation of variables.

\section{Conclusions}

In this study, we examined the association between the female employee ratio and tax avoidance. Recent tax avoidance studies report that female executives improve firm value by increasing accounting transparency and reducing tax avoidance activities because of the female characteristics of being risk-averse and conservative [10-15]. In the same vein, we hypothesized that the female employees in a company may affect the decision making of the company by forming a risk-averse and conservative corporate environment. Ultimately, we propose that gender diversity in a company can develop corporate sustainability by reducing tax avoidance.

To verify this result, we empirically analyzed the association between the female employee ratio and tax avoidance using 14,761 firm-year data from listed Korean firms from 2010 to 2018. The results of the empirical tests are as follows. First, we found a negative association between the female employee ratio and tax avoidance at a $1 \%$ significance level. This means that the possibility of tax avoidance decreases by increasing the proportion of female employees. As a result, a company can improve its sustainability in terms of tax avoidance by forming a risk-averse and conservative corporate environment containing female employees. In addition, we tested both the effects of non-regular employees and using the measurements of Desai and Dharmapala (2006). Ultimately, both the additional test and the robustness test provided results consistent with our hypothesis.

This study has made some contributions. First, this is the first study to examine the effects of female human resources on tax avoidance within the context of a Korean stock market setting. Second, the prior literature was only focused on the effects of female executives on corporate decision making. However, we examined the influence of overall female employees in this study. We provided empirical results that female employees create a more conservative and risk-averse corporate environment and improve the sustainability of a company by preventing tax avoidance activities. Lastly, this study suggests that the diversity of employee resources can act as additional determinants of tax avoidance, and we hope that our findings will offer some insights for academia and market practitioners regarding female human resources. 
Author Contributions: Conceptualization, C.S.R., S.W. and D.H.K.; methodology, C.S.R. and D.H.K.; software, D.H.K.; validation, C.S.R. and S.W.; formal analysis, S.W., and D.H.K.; investigation, C.S.R.; data curation, D.H.K.; writing-original draft preparation, S.W., and D.H.K.; writing-review and editing, C.S.R. and S.W.; supervision, S.W.; project administration, C.S.R. All authors have read and agreed to the published version of the manuscript.

Funding: This research is based support of 2019 Woosong University Academic Research Funding.

Acknowledgments: The authors are grateful to the anonymous reviewers, who have provided constructive ideas and insightful comments for this study.

Conflicts of Interest: The authors declare no conflict of interest.

\section{References}

1. Dyreng, S.; Hanlon, M.; Maydew, E. Long-Run Corporate Tax Avoidance. Account. Rev. 2008, 83, 61-82. [CrossRef]

2. Slemrod, J. The Economics of Corporate Tax Selfishness. Natl. Tax J. 2004, 57, 877-899. [CrossRef]

3. Slemrod, J.; Yitzhaki, S. Tax Avoidance Evasion, and Administration. Handb. Public Econ. 2002, 3, $1423-1470$.

4. Hanlon, M.; Heitzman, S. A Review of Tax Research. J. Account. Econ. 2010, 50, 127-178. [CrossRef]

5. Chun, H. Corporate International Diversification and Tax Avoidance. J. Tax. Account. 2013, 14, $175-197$.

6. Armstrong, C.; Blouin, J.; Jagolinzer, A.D.; Larcker, D.F. Corporate Governance, Incentive, and Tax Avoidance. J. Account. Econ. 2015, 60, 1-17. [CrossRef]

7. Desai, A.; Dharmapala, D. Corporate Tax Avoidance and High Powered Incentives. J. Financ. Econ. 2006, 79, 145-179. [CrossRef]

8. Kim, J.; Li, Y.; Zhang, L. Corporate Tax Avoidance and Stock Price Crash Risk: Firm-level Analysis. J. Financ. Econ. 2011, 100, 639-662. [CrossRef]

9. Balakrishnan, K.; Blouin, J.; Guay, W. Tax Aggressiveness and Corporate Transparency. Account. Rev. 2019, 94, 45-69. [CrossRef]

10. Francis, B.B.; Hasan, I.; Wu, Q.; Yan, M. Are Female CFOs Less Tax Aggressive? Evidence from Tax Aggressiveness. J. Am. Tax. Assoc. 2014, 36, 171-202. [CrossRef]

11. Shin, J.; Lee, G. The Role of Female Executives in Determining Tax Avoidance and the Market Response to the Tax Avoidance. J. Tax. Account. 2018, 19, 33-63.

12. Croson, R.; Gneezy, U. Gender Differences in Preferences. J. Econ. Lit. 2009, 47, 448-474. [CrossRef]

13. Sunden, A.; Surette, B. Gender Differences in the Allocation of Assets in Retirement Savings Plans. Am. Econ. Rev. 1998, 88, 207-211.

14. Schubert, R. Analyzing and Managing Risks-on the Importance of Gender Difference in Risk Attitudes. Manag. Financ. 2006, 32, 706-715. [CrossRef]

15. Olsen, R.A.; Cox, C.M. The Influence of Gender on the Perception and Response to Investment Risk: The Case of Professional Investors. J. Psychol. Financ. Mark. 2001, 2, 29-36. [CrossRef]

16. The Gab between Men's and Women's College Entrance Rates is Greatest. The Gap in Employment Rates is Also Narrowing. Available online: https://www.yna.co.kr/view/MYH20190701019600038?section=video/all (accessed on 2 February 2019).

17. Leopold, T.A.; Ratcheve, V.; Zahidi, S. The Global Gender Gap Report 2017; World Economic Forum: Geneva, Switzerland, 2017; pp. 1-361.

18. Lev, N.; Nissim, D. Taxable Income, Future Earnings, and Equity Value. Account. Rev. 2004, 79, $1039-1074$. [CrossRef]

19. Koh, Y.; Kim, J.; Choi, W. A Study on Corporate Tax Avoidance. Korean J. Tax. Res. 2007, 24, 9-40.

20. Chen, X.; Hu, N.; Wang, X.; Tang, X. Tax Avoidance and Firm Value: Evidence from China. Nankai Bus. Rev. Int. 2014, 5, 25-42. [CrossRef]

21. Ausin, C.R.; Wilson, R.J. An Examination of Reputational Costs and Tax Avoidance: Evidence from Firms with Valuable Consumer Brands. J. Am. Tax. Assoc. 2017, 39, 67-93. [CrossRef]

22. Daily, C.M.; Certo, S.T.; Dalton, D.R. A Decade of Corporate Women: Some Progress in the Boardroom, None in the Executive Suite. Strateg. Manag. J. 1999, 20, 93-99. [CrossRef]

23. Cassell, C. The Business Case for Equal Opportunities: Implications for Women in Management. Women Manag. Rev. 1997, 12, 11-17. [CrossRef] 
24. Bantel, K.; Jackson, S. Top Management and Innovations in Banking: Does the Composition of the Top Team Makes a Difference? Strateg. Manag. J. 1989, 10, 107-124. [CrossRef]

25. Joshi, A.; Roh, H. The Role of Context in Work Team Diversity Research: A Meta-Analytic Review. Acad. Manag. J. 2009, 52, 599-628. [CrossRef]

26. Kim, Y.; Hong, J. The Effects of the Number of Female Directors on the Board to Corporate Transparency. Korea Int. Account. Rev. 2015, 2, 69-100.

27. Adams, R.; Ferreira, D. Women in the Boardroom and Their Impact on Governance and Performance. J. Financ. Econ. 2009, 94, 291-309. [CrossRef]

28. Adams, R.; Hermalin, B.; Weisbach, M. The Role of Boards of Directors in Corporate Governance: A Conceptual Framework and Survey. J. Econ. Lit. 2010, 48, 58-107. [CrossRef]

29. Bernardi, R.; Arnold, D. An Examination of Moral Development within Public Accounting by Gender, Staff Level, and Firm. Contemp. Account. Res. 1997, 14, 653-668. [CrossRef]

30. Huang, J.; Kisgen, D. Gender and Corporate finance: Are Male Executives Overconfident Relative to Female Executives? J. Financ. Econ. 2013, 108, 822-839. [CrossRef]

31. Kim, N.; Kang, M.; Park, G.; Chon, B.; Park, M. Korean Women Manager Panel in 2015; Korean Women's Development Institute: Seoul, Korea, 2015.

32. Eagly, A.H.; Johannesen-Schmidt, M.C.; van Engen, M.L. Transformational, Transactional, and Laissez-Faire Leadership Styles: A Meta-Analysis Comparing Women and Men. Psychol. Bull. 2003, 129, 569-591. [CrossRef]

33. Jianakoplos, N.A.; Bernasek, A. Are Women More Risk Averse? Econ. Inq. 1998, 36, 620-630. [CrossRef]

34. Bernasek, A.; Shwiff, S. Gender, Risk, and Retirement. J. Econ. Issues 2001, 35, 345-356. [CrossRef]

35. Kang, J.; Kim, Y. Corporate Tax Avoidance and Ownership Structure. Korean J. Tax. Res. 2012, 29 , 37-67.

36. Kim, H.; Jeong, S. Gender Diversity in Employees and Discretionary Accruals: The Korean Evidence. Int. J. Account. Inf. Manag. 2018, 26, 362-383. [CrossRef]

37. Stocker, J.; Velde, M.; Lammers, J. Factors Relating to Managerial Stereotypes: The Role of Gender of the Employee and the Manager and Management Gender Ratio. J. Bus. Psychol. 2012, 27, 31-42. [CrossRef] [PubMed]

38. Lee, J.; Lee, Y. The Influence of Perceived Organizational Support \& Voluntary Choice on Nonstandard Workers' Job Satisfaction. J. Organ. Manag. 2015, 39, 35-61.

39. Cho, B.; Kim, K. The Effect of Fixed-term Employment Workers' Voluntary Choices Regarding Their Work Arrangements on Job Attitudes. Korean J. Manag. 2013, 21, 1-30.

40. Lee, Y. Empirical Analysis on the Reasons for Using Different Types of Nonstandard Workers and Its Implications. Korean J. Manag. 2016, 24, 9-40.

41. Wilkin, C. I Can't Get No Job Satisfaction: Meta-analysis Comparing Permanent and Contingent Workers. J. Organiz. Behav. 2013, 34, 47-64. [CrossRef]

42. Kalleberg, A. Nonstandard Employment Relations: Part-time, temporary and Contract Work. Annu. Rev. Sociol. 2000, 26, 341-364. [CrossRef]

43. Connelly, C.; Gallagher, D. Emerging Trends in Contingent Work Research. J. Manag. 2004, 30, $959-983$. [CrossRef]

44. De Cuyper, N.; De Jong, J.; De Witte, J.; Isaksson, K.; Rigotti, T.; Schalk, R. Literature Review of Theory and Research on the Psychological Impact of Temporary Employment: Towards a Conceptual Model. Int. J. Manag. Rev. 2008, 10, 25-51. [CrossRef]

45. Baek, H. The Wage Difference, Inequality and Poverty between Regular Work and Non-Regular Work: Focusing on the Age Group. Soc. Welf. Policy 2013, 40, 75-105. [CrossRef]

46. Kim, G.; Kim, M. Wage Differentials between Non-regular and Regular Workers by Union. Korean J. Ind. Relat. 2013, 23, 71-92.

47. National Tax Service. Available online: https://www.nts.go.kr/support/support_01.asp?cinfo_key= MINF8420100716140904 (accessed on 26 October 2019).

48. Son, U.; Yang, D.; Lee, S.; Kim, K. A Study on the Effect of Corporate Governance Structure on the Relationship between Tax Sheltering and Firm Value. J. Tax. Account. 2012, 13, 385-419.

49. Kim, J.; Jeong, J. The Effect of Corporate Financial Characteristics on Tax Avoidance. Korean J. Tax. Res. 2006, $23,97-123$. 
50. Park, M. Auditor's Characteristics and Tax Avoidance. J. Tax. Account. 2012, 13, 191-219.

51. Keum, B.; Kweon, S. The Relations between Tax Avoidance and Cash Holdings: View from the Largest Shareholder's Holding. Korea Int. Account. Rev. 2013, 50, 107-130. [CrossRef]

(C) 2019 by the authors. Licensee MDPI, Basel, Switzerland. This article is an open access article distributed under the terms and conditions of the Creative Commons Attribution (CC BY) license (http://creativecommons.org/licenses/by/4.0/). 